\title{
Pengaruh Model Reciprocal Teaching Dipadukan dengan Think Pair Share terhadap Hasil Belajar Mikrobiologi Mahasiswa IKIP Budi Utomo
}

\author{
Purwaning Budi Lestari \\ Program Studi Pendidikan Biologi IKIP Budi Utomo \\ Jalan Citandui 46 Malang \\ Purwaning.budilestari@gmail.com \\ Titik Wijayanti \\ Program Studi Pendidikan Biologi IKIP Budi Utomo \\ Jalan Citandui 46 Malang
}

\begin{abstract}
Location of observation results were obtained preliminary data the value of the results obtained from the study of microbiology student class of 2012 a number of 297 students with a range (86-100) of $20 \%$ or 60 students, students with a range of values (70-85) by $23 \%$ or 68 students, while the value of students under 70 sebasar 57\% or 169. The purpose of this research is as follows: Determine the influence learning model Think Pair Share Reciprocal Teaching combined with the learning outcomes of students. The study design is a quasi-experimental design (Quasi experiments). Research data analysis techniques performed by using analysis of covariance (Anacova). The results showed the average value of the lowest corrected is control by the conventional approach of 63102 followed by 68. 923 polling stations, amounting to 71. 587 the next Reciprocal Teaching and TPS $+R T$ amounted to 81. 644. Test homogeneity of variance between different groups or homogeneous data. , An average of 4 models fell from above that showed significant are: the integration of TPS $+R T R T$ significantly different, real different to the polling stations and significantly different to conventional (control). But for TPS and $R T$ models are not significantly different.
\end{abstract}

Keywords: Model Reciprocal Teaching, Think Pair Share, Microbiology Learning Outcomes

Pentingnya belajar mikrobiologi, selain mengkaji pengetahuan tentang makhluk hidup, juga usaha untuk menumbuhkan dan mengembangkan sikap, keterampilan berpikir, serta meningkatkan keterampilan untuk menjalankan metode penyelidikan ilmiah dalam bidang mikrobiologi melalui langkahlangkah metode ilmiah. Mikrobiologi perlu lebih mengoptimalkan kemampuan mahasiswa harapannya dapat membentuk kepribadian mandiri, berpola, kreatif, dan objektif yang memiliki karakter (softskill) dalam penampilan, sikap, dan tingkat laku. Oleh sebab itu peningkatan kualitas mahasiswa perlu ditingkatkan melalui proses pembelajaran yang bersifat kontruktivisme.
Salah satu strategi pembelajaran yang berorentasi kontruktivistik dan learning community yaitu pembelajaran cooperative learning (Arend, 2004 dalam Muhfaroyin 2009). Corebima (2007) menyatakan bahwa strategi cooperative learning sangat berpotensi memberdayakan pemahaman konsep dan kemampuan berpikir peserta didik. Strategi cooperative learning memiliki bermacammacam tipe yang dapat dikembangkan, diantaranya adalah Think Pair Share (TPS) dan Reciprocal Teaching. Prinsip kegiatan pembelajaran strategi Reciprocal Teaching yang pertama adalah menyusun pertanyaan (question generating). Kegiatan menyusun pertanyaan dapat melatih keterampilan berpikir kritis. Kegiatan menyusun pertanyaan 
merupakan usaha mengembangkan rasa ingin tahu siswa untuk memperoleh beberapa informasi. Prinsip kegiatan pembelajaran kedua dari strategi Reciprocal Teaching adalah kegiatan memprediksi (Prediction). Kegiatan memprediksi dapat melatih mahasiswa dalam mengambil keputusan dalam menghadapi permasalahan yang dihadapi siswa misalnya dalam menjawab pertanyaan (Palincsar, 2004). Selanjutnya untuk prinsip strategi Reciprocal Teaching kegiatan yang ketiga yaitu kegiatan mengklarifikasi (Clarifying). Kegiatan mengklarifikasi, melatih mahasiswa mengidentifikasi informasi. Seperti menjawab pertanyaan, bila mahasiswa tidak dapat menjawab maka akan mencari sumber lain yang mendukung, misalnya membaca kembali bacaan yang ada atau bacaan dari sumber lain. Prinsip kegiatan yang keempat adalah merangkum (Summarizing). Kegiatan merangkum, melatih siswa dalam mengelola informasi. Kegiatan merangkum diperlukan aktivitas membaca, memunculkan ide dan merangkum ide. Sedangkan model pembelajaran Think Pair Share merupakan salah satu cooperative learning yang dikembangkan oleh Lyman, 1985. Menurut Susilo (2005) model TPS mudah digunakan, yaitu dengan cara guru memberikan pertanyaan,memikirkan dan mendiskusikan dengan pasangannya, serta menyampaikan keseluruh kelas. TPS memperkenalkan ide waktu berpikir atau waktu tunggu yang banyak menjadi factor utama dalam meningkatkan kemampuan peserta didik untuk merespon pertanyaan. Istilah TPS berasal dari tiga tahapan kegiatan yang menekankan pada apa yang dikerjakan pada setiap tahapan, Think berarti berpikir, Pair berarti berpasangan dan Share berarti berbagi. Sintaks pembelajaran TPS menjelaskan bahwa pengajar memberikan pertanyaan kemudian selanjutnya dibuat kelompok berpasangan untuk mendiskusikan jawaban atas pertanyaan tersebut. Implementasi strategi pembelajaran TPS akan terbangun hubungan social antar mahasiswa serta melatih komonikasi.

Hasil Belajar, Menurut Suharsimi Arikunto (1990) hasil belajar adalah hasil yang dicapai seseorang setelah melaksanakan kegiatan belajar dan merupakan penilaian terhadap siswa untuk mengetahui sejauh mana bahan pelajaran atau materi yang diajarkan dapat dikuasai oleh siswa. Untuk dapat menentukan tercapainya tujuan pembelajaran dilakukan usaha untuk menilai hasil belajar. Penilaian ini bertujuan untuk melihat kemajuan peserta didik dalam penguasaan materi yang dipelajari dan ditetapkan. Menurut Slameto (1995) hasil belajar merupakan sesuatu yang dicapai dari suatu usaha dalam mengikuti pendidikan atau latihan tertentu yang hasilnya dapat ditentukan dengan memberi tes pada akhir pendidikan. Disamping sebagai indikator keberhasilan belajar dapat berguna sebagai evaluasi dalam proses pembelajaran.

Data nilai Hasil observasi dilokasi penelitian diperoleh data awal sebagai berikut nilai hasil belajar mikrobiologi yang diperoleh dari mahasiswa angkatan 2012 sejumlah 297 mahasiswa dengan rentang (86-100) sebesar $20 \%$ atau 60 mahasiswa, nilai mahasiswa dengan rentang (70-85) sebesar $23 \%$ atau 68 mahasiswa, sedangkan nilai mahasiswa dibawah 70 sebasar $57 \quad \%$ atau 169 . Berdasarkan latar belakang yang telah diuraikan di atas, rumusan masalah dalam penelitian ini adalah sebagai berikut: Apakah pengaruh model pembelajaran Think Pair Share dipadukan dengan Reciprocal Teaching terhadap hasil belajar mahasiswa.

\section{METODE}

Teknik analisis data hasil penelitian dilakukan dengan menggunakan analisis kovarian (Anacova). Sebelum dilakukan analisis kovarian terlebih dahulu dilakukan uji prasarat untuk melihat apakah data yang digunakan dalam penelitian telah didistribusikan dengan normal dan homogen atau sebaliknya dengan menggunakan uji homogenitas dan uji normalitas varians. Uji lanjut menggunakan uji beda LSD. Hipotesis penelitian (Ha) akan diterima jika Fh. Ft pada tarap kepercayaan 95\%. Penghitungan uji statistic pada penelitian dibantu program SPSS 16 for Windows. Analisis rata-rata skor digunakan untuk mendiskripsikan hasil belajar. 
HASIL

Pengembangan Perangkat Pembelajaran

Hasil penelitian menunjukkan bahwa perangkat pembelajaran dapat digunakan dalam proses pembelajaran dengan beberapa catatan. Interprestasi RPP; (1) dapat digunakan untuk mencapai kompetensi dasar, (2) dapat digunakan untuk mencapai indicator pencapaian kompetensi, (3) sesuai dengan perpaduan antara Think Pair Share dan

Reciprocal Teaching, (4) dapat diterapkan pada materi yang relevan, (5) sesuai dengan waktu yang tersedia, dan (6) penerapannya menggunakan bahasa yang jelas.

\section{Diskripsi Umum Hasil Penelitian Eksperimen}

a. Deskripsi Rata-Rata Nilai Pretes dan Post Tes Hasil Belajar Mikrobiologi
Rata-rata nilai hasil belajar pretes beserta kategorinya dapat dijelaskan sebagai berikut; rata-rata skor hasil belajar pretes pada semua kelompok subyek penelitian termasuk pada kategori kurang. Kelompok tersebut yaitu model TPS, model Reciprocal Teaching dan perpaduan/integrasi TPS dan Reciprocal Teaching dan strategi konvensional. Rata-rata nilai hasil belajar post tes beserta kategorinya dapat dijelaskan sebagai berikut; rata-rata skor hasil belajar pretes pada semua kelompok subyek penelitian termasuk pada kategori kurang. Kelompok tersebut yaitu strategi TPS, strategi Reciprocal Teaching dan perpaduan/integrasi TPS dan Reciprocal Teaching, serta strategi konvensional. Ratarata nilai pre tes dan post tes dapat dilihat pada Tabel 1.1.

\begin{tabular}{|c|l|c|c|c|c|}
\hline No & Variable pembelajaran & Pretes & Kategori & Postes & Kategori \\
\hline 1. & TPS & 24.28571 & Kurang & 69.0179 & Baik \\
\hline 2. & Reciprocal Teaching & 20.69264 & Kurang & 69.6190 & Baik \\
\hline 3. & TPS+RT & 26.77551 & Kurang & 82.7941 & Sangat Baik \\
\hline 4. & Konvensional & 25.2381 & Kurang & 63.5714 & Baik \\
\hline
\end{tabular}

Tabel 1.1 Rata-rata Nilai Pretes dan Post Tes Hasil Belajar

\section{Analisis data dan pengujian hipotesis}

Uji statistic digunakan untuk mengetahui pengaruh perlakuan terhadap variable terikat. Teknik analisis data yang digunakan untuk mengetahui pengaruh perlakuan dalam penelitian ini adalah analisis kovarian (anakova), dengan pretes sebagai kovarian. Sebelum dilakukan uji anakova terlebih dilakukan uji asumsi, meliputi uji homogenitas data. Uji homogenitas antar varian data menggunakan Levene's Test of Equality of Error Varians.

\section{- Uji homogenitas}

Uji homogenitas dilakukan terhadap data post tes hasil belajar terkoreksi. Hasil uji homogenitas hasil belajar ditampilkan pada Tabel 4.3. Berdasarkan perhitungan diperoleh signifikasi. (p-level) lebih besar dari 0,05 (p.0,05), hal ini menunjukkan bahwa $\mathrm{H} 0$ diterima, jadi varian antar kelompok data tidak berbeda atau homogeny.

\begin{tabular}{|c|c|c|c|}
\hline F & df1 & df2 & Sig. \\
\hline 5.075 & 3 & 128 & .002 \\
\hline
\end{tabular}

Tabel 1.2. Hasil Uji Homogenitas Antar Varian dengan Levene Test Hasil belajar

Berdasakan uji homogenitas menunjukkan varian antar kelompok data homogen, maka data hasil belajar memenuhi persyaratan uji parametrik.

- Uji hipotesis

a. Uji hipotesis Variabel Terikat Hasil Belajar

Hasil penghitungan analisis statistic anakova variable terikat hasil belajar secara lengkap disajikan pada lampiran (12) Ringkasan uji Hipotesis terdapat pada Tabel 1.3 berikut. 


\begin{tabular}{|l|r|r|r|r|r|}
\hline Source & $\begin{array}{c}\text { Type III Sum of } \\
\text { Squares }\end{array}$ & Df & Mean Square & F & \multicolumn{1}{c|}{ Sig. } \\
\hline Corrected Model & $8789.719^{\mathrm{a}}$ & 4 & 2197.430 & 16.740 & .000 \\
\hline Intercept & 57096.206 & 1 & 57096.206 & 434.954 & .000 \\
\hline PRETES_HSL & 1896.976 & 1 & 1896.976 & 14.451 & .000 \\
\hline MODEL & 6211.611 & 3 & 2070.537 & 15.773 & .000 \\
\hline Error & 16671.240 & 127 & 131.270 & & \\
\hline Total & 694956.635 & 132 & & & \\
\hline Corrected Total & 25460.958 & 131 & & & \\
\hline
\end{tabular}

Tabel 1.3 Ringkasan Hasil Uji Anakova Pengaruh Perlakuan terhadap Hasil Belajar

Berdasarkan hasil uji statistic anakova pengaruh perlakuan hasil belajar dapat diinterprestasikan sebagai berikut:

1. Model Pembelajaran

Berdasarkan Tabel 1.3 terlihat bahwa model pembelajaran diperoleh $\mathrm{p}$-level lebih kecil dari alpha $0,05 \quad(\mathrm{p}, 0,05)$ dengan signifikasi 0,000 . Berarti H0 yang menyatakan "tidak ada pengaruh model pembelajaran terhadap hasil belajar" tidak diterima, sehingga hipotesis penelitian yang menyatakan "Ada pengaruh model pembelajaran terhadap hasil belajar mahasiswa", diterima.

Untuk mengetahui perbedaan rata-rata terkoreksi dari masing-masing perlakuan selanjutnya dilakukan uji lanjut dengan menggunakan teknik analisis LSD, ringkasan uji lanjut perlakuan terhadap hasil belajar dapat dilihat pada Tabel 1.4 berikut.

\begin{tabular}{|l|c|c|}
\hline \multicolumn{1}{|c|}{ Model } & $\begin{array}{c}\text { Mean } \\
\text { (Rerata) }\end{array}$ & Notasi \\
\hline Kontrol & 63.102 & $\mathrm{a}$ \\
\hline TPS & 68.923 & $\mathrm{~b}$ \\
\hline RT & 71.587 & $\mathrm{~b}$ \\
\hline TPS+RT & 81.644 & $\mathrm{c}$ \\
\hline
\end{tabular}

Tabel 1.4 Ringkasan Uji lanjut Model Pembelajaran Terhadap Hasil Belajar

Tabel1.4 diatas menunjukkan perbedaan rata-rata nilai hasil belajar terkoreksi pada masing-masing model. Rata-rata nilai terkoreksi dari yang paling rendah adalah control dengan pendekatan konvensional sebesar 63.102 kemudian disusul TPS sebesar 68.923, selanjutnya Reciprocal Teaching sebesar 71.587 dan TPS+RT sebesar 81.644. tabel 4.5 juga menunjukkan bahwa nilai ratarata terkoreksi dari 4 model diatas yang menunjukkan signifikan yaitu: integrasi
TPS+RT menunjukkan perbedaan yang signifikan dengan RT, berbeda secara signifikas TPS dan berbeda secara signifikas konvensional yang digunakan sebagai kontrol. Namun untuk model TPS dan RT tidak berbeda nyata.

\section{PEMBAHASAN}

Perangkat pembelajaran yang dikembangkan pada penelitian ini meliputi: silabus dan Rencana Pelaksanaan pembelajaran yang berisi langkah-langkah yang sesuai dengan strategi pembelajaran. Penilaian perangkat pembelajaran dilakukan oleh tim ahli dalam hal ini validator. Tanggapan validator terhadap penerapan pembelajaran yang diterapkan pada penelitian ini secara umum telah dapat mencapai kompetensi dasar yang ditentukan, dapat mencapai indicator. Hal tersebut dapat dilihat dari peningkatan hasil belajar.

\section{Pengaruh Strategi Pembelajaran terhadap hasil belajar}

Hasil uji anakova pada penelitian ini menunjukkan bahwa strategi pembelajaran berbeda nyata terhadap hasil belajar mahasiswa. Hal ini dapat dijelaskan pada masing-masing strategi pembelajaran mempunyai karakteristik yang berbeda satu sama lain. Penelitian yang menunjang pernyataan diatas adalah penelitian yang dilakukan oleh Corner (2007) dalam Suratno (2009), yang menyatakan bahwa kebayakan peserta didik menyadari bahwa strategi pembelajaran cukup membentu dalam meningkatkan hasil belajar. setiap strategi pembelajaran memiliki kekhasan yang bisa 
digunakan sesuai dengan karakter materi mata kuliah tertentu.

Pada penelitian ini model Think Pair Share, Reciprocal Teaching, dan integrasi Think Pair Share dan Reciprocal Teaching berbeda nyata terhadap hasil belajar mikrobiologi. Mahasiswa yang belajar menggunakan strategi TPS, Reciprocal Teaching, dan integrasi TPS dan Reciprocal teaching mengalami peningkatan rata-rata nilai hasil belajar mikrobiologi lebih tinggi dibandingkan mahasiswa yang belajar dengan strategi konvensional. Hal tersebut senada dengan yang disampaikan oleh Komarudin Hidayat (2001) upaya untuk meningkatkan keberhasilan pendidikan adalah menggunakan pembelajaran aktif dimana siswa melakukan sebagian besar kegiatan yang harus dilakukan. Belajar aktif merupakan langkah cepat,menyenangkan,mendukung dan menarik hati dalam belajar. Untuk mempelajari sesuatu dengan baik, belajar aktif membantu untuk mendengarkan, melihat, mengajukan pertanyaan tentang pelajaran tertentu dan mendiskusikannya dengan mahasiswa yang lain. Yang paling penting mahasiswa perlu melakukannya, memecahkan masalah sendiri, mencoba ketrampilan-ketrampilan dan melakukan tugas-tugas yang tergantung pada pengetahuan yang dimiliki.

Skor rata-rata hasil belajar antara mahasiswa dengan strategi pembelajaran integrasi Think Pair Share dan Reciprocal Teaching lebih tinggi dibandingkan dengan strategi pembelajaran Reciprocal Teaching, Think Pair Share dan konvensional. Hal ini disebabkan oleh penerapan scenario strategi intergrasi Think Pair Share dan Reciprocal Teaching dimana model Think Pair Share mengutamakan pada pembelajaran kooperatif yang memungkinkan mahasiswa untuk saling membantu dan berinteraksi satu sama lainnya. Dimana menurut Sukamto, dkk. (2013) menyatakan Pembelajaran kooperatif (cooperative learning) adalah pendekatan pembelajaran yang berfokus pada penggunaan kelompok kecil siswa untuk bekerja sama dalam memaksimalkan kondisi belajar untuk mencapai tujuan belajar. Pembelajaran kooperatif menciptakan interaksi yang asah,asih,dan asuh sehingga tercipta masyarakat belajar (learning community).
Menurut Muslimin Ibrahim (2000) hasil-hasil penelitian menunjukan bahwa teknik-teknik pembelajaran kooperatif lebih unggul dalam meningkatkan hasil belajar dibandingkan dengan pengalaman-pengalaman belajar individu atau kompetitif.

Sementara itu model Reciprocal Teaching memiliki kelebihan pada sintaks yang memungkinkan mahasiswa dapat membaca, meringkas, membuat pertanyaan, memprediksi jawaban serta mengklarifikasi jawaban sebelum dosen memberikan pemantapan. Hal ini akan memungkinkan mahasiswa lebih banyak memahami materi pembelajaran, karena dengan melakukan serangkaian sintaks tersebut mahasiswa akan membaca dan memahami materi pembelajaran.

Hasil penelitian menunjukkan bahwa model pembelajaran integrasi Reciprocal Teaching dengan Think Pair Share memiliki presentase peningkatan yang paling besar, disusul kemudian model Reciprocal Teaching, model Think Pair Share dan yang paling rendah presentase peningkatannya adalah model konvensional. Tinggingnya persentase hasil belajar yang menggunakan model Reciprocal Teaching juga terjadi pada penelitian sebelumya yang dilakukan oleh Hadi (2006), Budi (2009), dan Zusye (2009). Hal senada juga terjadi pada penelitian Suratno (2009) dimana strategi Reciprocal Teaching dapat meningkatkan hasil belajar peserta didik. Jika dilihat dari sintak pembelajaran Reciprocal Teaching maka elemen penting strategi Reciprocal Teaching yang dapat meningkatkan perolehan hasil belajar adalah menyusun pertanyaan. Menurut Brown dan Walton (1995) dalam Zusye (2009) bahwa penyusunan pertanyaan memiliki 2 tahap kognitif yaitu tahap accepting (menerima) dan tahap challenging (menantang) terjadi pada saat mahasiswa membuat pertayaan. Proses accepting (menerima) memungkinkan peserta didik menempatkan suatu informasi pada suatu jaringan struktur kognitif, sedangkan proses kognitif challenging (menantang) dapat memungkinkan jaringan yang ada pada diri peserta didik akan semakin kuat hubungannya (Marzuki 2005, dalam Zusye 2009).

Model Think Pair Share berbeda nyata terhadap peningkatan hasil belajar kognitif 
mahasiswa. Model Think Pair Share merupakan pembelajaran kooperatif yang menekankan pada kemampuan berfikir yang secara emplisit dijelaskan oleh Arends (2004), Susilo (2005), dan Zubaidah (2005) bahwa seorang guru yang membelajarkan peserta didik dengan strategi Think Pair Share akan memulai dengan Thinking, pada tahap ini guru mengajukan pertanyaan pada peserta didik yang berhubungan dengan materi pelajaran, selanjutnya peserta didik akan berfikir sendiri. Tahap yang kedua adalah Pairing, pada tahap ini peserta didik saling berpasangan sehingga terjadi komunikasi dengan temannya, Slavin (1995) menjelaskan bahwa dengan adanya komunikasi antara peserta didik yang satu dan yang lain dalam berpasangan akan membangkitkan hubungan social antar peserta didik, melatih komunikasi, dan saling berdiskusi tentang materi pembelajaran. Interaksi social dengan teman sebaya melalui kerja kelompok mendorong terbentuknya ide dan memperkaya perkembangan mental anak (Ibrahim dan Nur, 2000). Terakhir adalah tahap sharing, pada tahap ini mahasiswa berbagi hasil diskusi dalam forum perkuliaahan sehingga seluruh kelas dapat mengetahui jawaban atas pertanyaan dari pasangan lainnya.

Pada model pembelajaran kooperatif tipe TPS (Think Pair Share), mahasiswa dapat mengembangkan dan melatih berbagai sikap, nilai, dan ketrampilan. Siswa tidak hanya sebagai obyek belajar melainkan juga sebagai subyek belajar karena siswa dapat menjadi teman diskusi aktif bagi siswa pasangannya (Siti Maesuri, 2002). Dalam diskusi, mahasiswa dilatih untuk bekerjasama, karena bukan hanya materi yang dipelajari tetapi juga tuntutan untuk mengembangkan potensi dirinya secara optimal bagi kesuksesan kelompoknya. Seperti yang dijelaskan oleh Thelma Reiss dalam Slavin (2008: 165) adalah penting bahwa penghargaan kelompok atau tim diberikan melalui cara-cara yang bervariasi dan bermanfaat. Siswa menjadi antusias dalam kegiatan diskusi, sehingga banyak siswa yang mendapatkan penghargaan dan berpartisipasi aktif sehingga dimungkinkan nilai atau hasil belajar siswa mengalami peningkatan., Agustina .A, 2013). Melalui model pembelajaran tipe TPS (Think
Pair Share), mahasiswa diberi kesempatan untuk belajar mencari jawaban dengan wawasan dan pengetahuan yang lebih luas bersama pasangannya atau kelompoknya, sehingga pada akhirnya apa yang dipelajarinya lebih bermakna bagi dirinya.

Kegiatan pembelajaran dengan menggunakan strategi konvensional menduduki urutan terendah, hal tersebut disebabkan karena pembelajaran dilakukan secara monoton sehingga membosankan dan menyebabkan motivasi ataupun minat belajar mahasiswa menurun. Factor lain yang menyebabkan rendahnya nilai rata-rata belajar dengan strategi konvensional adalah pengetahuan terkait dengan materi pembelajaran hanya pada saat guru/dosen menerangkan dan selebihnya mahasiswa membiarkan pengetahuan yang didapatnya tersebut hilang begitu saja sebelum kegiatan evaluasi dilakukan.

\section{KESIMPULAN DAN SARAN}

Berdasarkan hasil analisis data dan pembahasan dapat disimpulkan sebagai berikut:

1. Ada pengaruh model pembelajaran terhadap hasil belajar mahasiswa. berdasarkan uji lanjut LSD rata-rata nilai terkoreksi hasil belajar mahasiswa dari yang tertinggi sampai yang terendah secara berurutan terdapat pada model Reciprocal Teaching dipadukan dengan Think Pair Share, Reciprocal Teaching, Think Pair Share dan konvensional.

2. Berdasarkan taraf signifikasi model pembelajaran dapat disimpulkan bahwa nilai rata-rata terkoreksi dari 4 model menunjukkan signifikan yaitu: integrasi TPS+RT berbeda nyata terhadap Reciprocal Teaching, berbeda nyata terhadap TPS dan berbeda nyata terhadap pembelajaran konvensional yang digunakan sebagai kontrol. Namun untuk model Think Pair Share dan Reciprocal Teaching tidak berbeda nyata.

\section{DAFTAR RUJUKAN}

Arikunto, S. 2008. Dasar-dasar Evaluasi Pendidikan. Jakarta: Bumi Aksara. 
Desmita. 2006. Psikologi perkembangan. Bandung : PT. Remaja Rosdakarya.

Fauzi. A.M (Tanpa Tahun). Peranan kemampuan metakognitif dalam pemecahan masalah matematika sekolah.

Ismiati, L. 2011. Pengaruh Strategi Think Pair Share, Reciprocal Teaching dan Integrasinya terhadap Hasil Belajar Kognitif Biologi dan Kemampuan Berpikir Kritis Peserta didik Berkemampuan Akademik Berbeda di R-SMA-BI Negeri Batu. Tesis tidak diterbitkan. Malang: PPs UM

Muhfahroyin. 2009. Memberdayakan Kemampuan Berpikir Kritis, (Online), (http:zanikhan.multiply.com/journal/ite m/5570/Memberdaykan-KemampuanBerpikir-Kritis.Html). diakses tanggal 26 Desember 2014

Nurhadi, Y.B. dan Sanduk, A.G 2004. Pembelajaran Kontekstual dan Penerapannya dalan KBK, Malang; UNESA-University Press.

Noriasih, N.K. 1998. Penyusunan Pertanyaan dan Penerapannya dalam Persaingan Kelompok untuk Meningkatkan Pemahaman Isi Bacaan Siswa Kelas IA SLTP Laboratorium STKIP Singaraja. Skripsi (tidak diterbitkan). Singaraja: STKIP Singaraja.

Palinscar. A. S. 1986. Reciprocal Teaching (http://www.education.umm.edu/) diakses 3 April 2012.

Schraw \& Denisson. 1994. Assesing Metakognitive Awareness. Contemporary Educational phycology. (online)

(http://www.mendeley.com/research/ass esing-metakognitive-awareness/page 1), diakses tanggal 20 Januari 2013

Susanti, E. 2004. Memperbaiki Kualitas Proses Belajar Genetika Melalui Strategi
Metakognitif dalam Pembelajaran

Kooperatif pada siswa SMU. Disertasi tidak diterbitkan. Malang: PPS UM.

Veenman, M.V.J, Hout-Wolter, B.H.A.M.V, \& Afflerbach, P. Metaconition and Learning: Conceptual and Methodological Considerations. 2006. Springer Science. 1:3-14

Widiya Pakartining Kawedar dan Abdul Qohar. 2010. Penerapan Model Pembelajaran Reciprocal Teaching Untuk Meningkatkan Hasil Belajar Siswa Pada Pokok Bahasan Segitiga Siswa Kelas VII-C SMP Negeri 2 Kepanjen. Skripsi Tidak Diterbitkan. Malang: Jurusan Matematika Universitas Negeri Malang.

Wicaksono. A.G.C, 2014. Hubungan Ketrampilan Metakognitif Dan Berpikir Kritis Terhadap Hasil Belajar Siswa SMA Pada Pembelajaran Biologi Dengan Strategi Reciprocal Teaching Di Kabupaten Malang: Tesis tidak diterbitkan. Malang: PPs UM

Sudjana N. (2004). Landasan psikologi proses pendidikan. PT Remaja Rosdakarya

Risqi, E. (2014) Penerapan Model Reading Map Group Investigation (GI) Untuk Meningkatkan Minat Baca, Kemampuan Berpikir Kritis, Kesadaran Metakognitif Dan Hasil Belajar Biologi Siswa Kelas $\mathrm{X}$ SMA Surya Buana Malang: Tesis tidak diterbitkan. Malang: PPs UM

Rusmaryanti, D (2013). meningkatkan Hasil Belajar Biologi denganModel Pembelajaran Kooperatif Tipe TPS (Think Pair Share) pada Siswa kelas VIIIA MTs Al Huda 2 Jenawi Karanganyar Tahun Pelajaran 2012/2013. JURNAL PENDIDIKAN, VOLUME 22, NOMOR 3, NOPEMBER 2013. 